\title{
Isolation of Fungi in Musca domestica Linnaeus, 1758 (Diptera: Muscidae) Captured at Two Natural Breeding Grounds in the Municipality of Seropédica, Rio de Janeiro, Brazil
}

\author{
Márcia de Senna Nunes Sales, Gisela Lara da Costa*, Vânia Rita Elias \\ Pinheiro Bittencourt**/+
}

\begin{abstract}
Departamento de Parasitologia, Faculdade de Ciências Biológicas e da Saúde, Universidade Iguaçu, Nova Iguaçu, RJ, Brasil
*Departamento de Micologia, Instituto Oswaldo Cruz-Fiocruz, Rio de Janeiro, RJ, Brasil **Departamento de Parasitologia Animal, Instituto de Veterinária, Universidade Federal Rural do Rio de Janeiro, BR 465, km 7, 23890-000 Seropédica, RJ, Brasil
\end{abstract}

The objective of this study was to isolate and identify fungal species found in natural association with adults of Musca domestica. The adult insects were collected from two natural breeding grounds: hog pens and an urban sanitary landfill. The isolated fungi were identified as: Aspergillus flavus (23.8\%), A. niger var. niger (14.4\%), Penicillium corylophilum (21.4\%), P. fellutanum (11.9\%), Cladosporium cladosporoides (4.7\%), Fusarium $s p$. (4.7\%), Alternaria alternata (11.9\%), Curvularia brachyspora (2.4\%), Mycelia sterilia (2.4\%) and the Mucorales order (2.4\%).

Key words: Musca domestica - entomopathogenic fungus - isolation - biological control - Rio de Janeiro - Brazil

The housefly, Musca domestica, is important to sanitary medicine since it acts as a mechanical and/or biological vector for various pathogenic agents, including human and domestic animal parasites. These pathogens are transmitted on the fly's cuticle, proboscis, by regurgitation or through its feces. This species of fly has been found to spread etiological agents of typhoid and paratyphoid fevers, bacillary dysentery, cholera, hematic carbuncles, bovine mastitis (garget), conjunctivitis and poliomyelitis (Greenberg 1970, 1973, Gough \& Jorgenson 1983). This species has also been reported capable of carrying cysts of many protozoans, such as Entamoeba histolytica, E. coli, Giardia intestinalis, as well as the eggs of some helminths (Freitas et al. 1981).

According to Hall (1964), the idea of using species of fungi for insect control has been discussed since the XIX century. Entomopathogenic fungus species are cited as most effective in insect control programs (Hall \& Papierok 1982, Messias 1989).

Infestation of $M$. domestica by a Phycomycete of the genus Empusa (currently Entomophthora) was reported by Salles and Hathaway (1944). As a rule, captured flies were found stuck by the proboscis to objects where there had been deposition of fecal material. The authors noted that the species E. muscae had a marked preference for cold moist environments. They also stated that if it were possible to cultivate E. muscae artificially, it would be very useful in the prophylaxis of flies.

The association of fungi and insects has been verified by several authors (Steinhaus 1946, Gillian \& Prest 1972, Gillian et al. 1974, Costa \& Oliveira 1998, Madeira 1998, Norberg et al. 1999). Steinkraus et al. (1990) noticed that,

$\overline{{ }^{+} \text {Corresponding author. Fax: }}+55-21-2682.1617$. E-mail: vaniabit@ufrrj.br

Received 16 January 2002

Accepted 4 July 2002 in general, the experiments conducted with dipterons (gnats) use fungal species that were not originally isolated from gnats. However, in Brazil, there have been few studies aimed at the biological control of flies by entomopathogenic fungi and there is a lack of knowledge of the fungal species that live in natural association with these insects.

The objective of this study was to isolate and identify fungal species with entomopathogenic potential in adults of M. domestica.

\section{MATERIALS AND METHODS}

The experiment was carried out at the W.O. Neitz Parasitology Research Station (EPPWON) of the Department of Animal Parasitology at the Veterinary School of the Universidade Federal Rural do Rio de Janeiro (UFRRJ), during the period February 1999 to June 2000. Laboratory work was done under controlled conditions for temperature and relative humidity $\left(28^{\circ} \mathrm{C} \pm 1\right.$ and $\left.\geq 80 \%\right)$ at the Microbe Control Laboratory for Arthropods of Veterinary Importance and the Insect Biology Laboratory.

Adult insects of the species $M$. domestica were collected at two locations (natural breeding grounds) in the municipality of Seropédica, State of Rio de Janeiro. The first group was taken from pens at the Swine Breeding Sector of the Instituto de Zootecnia (UFRRJ) and the second from the city dump in the Boa Esperança district of the municipality. The flies were captured with a nylon net and a wooden cage covered on the sides by nylon netting ( $28.5 \mathrm{~cm}$ height $\times 27.5 \mathrm{~cm}$ width $\times 32 \mathrm{~cm}$ depth). Three collecting sessions were conducted at each location during February, May and September 1999.

After capture, the insects were separated in the laboratory and stored in test tubes in groups of ten specimens. Four tubes were separated out for each collection location and placed in a freezer for $5 \mathrm{~min}$ to anesthetize the insects. These tubes were then placed in a laminar flow chamber where the rest of the steps were carried out. All the instruments and culture media used in this step 
were previously sterilized in an autoclave. The adult flies were initially washed in a solution of $1 \%$ sodium hypochlorite for $3 \mathrm{~min}$ and twice in sterile distilled water for $1 \mathrm{~min}$ each (Seymour et al. 1984). The group of ten flies (test tube) was transferred to a crucible containing a $0.85 \%$ saline solution for maceration. In a laminar flow chamber, $0.1 \mathrm{ml}$ of this macerated preparation was retrieved and inoculated (spread using a Drigalski loop) in Petri dishes $(9 \mathrm{~cm})$ containing the medium PDA at $2 \%$, supplemented with chloranphenicol to inhibit bacteria growth. The $\mathrm{pH}$ had been corrected previously to 7.0 by the addition of $\mathrm{NaOH}$ at $1 \mathrm{~N}$. Five dishes were inoculated for each repetition, for a total of 20 dishes for each collection location. These inoculated dishes were kept in a climate controlled chamber at a temperature of $28^{\circ} \mathrm{C} \pm 1$ and relative humidity of $\geq 80 \%$. Daily observations were made for 15 days. Each isolated colony was identified according to the following parameters: location of fly capture $(\mathrm{S}=$ swine and $\mathrm{L}=$ landfill), pool number of the macerated flies and number of the colony in each Petri dish .

The cultured and identified colonies were then transferred to test tubes $(16 \times 160 \mathrm{~mm})$ containing $10 \mathrm{ml}$ of PDA, prepared as described above, and cooled at an inclination of $30^{\circ}$ (Alves 1998). These tubes were kept in a chamber under the same conditions of $28^{\circ} \mathrm{C} \pm 1$ and relative humidity of $\geq 80 \%$.

The fungi species were identified at the Fungi Culture Collection Laboratory of the Department of Mycology of the Instituto Oswaldo Cruz-Fiocruz. In order to observe the macroscopic characteristics of each isolate, fragments of the colony grown in the test tubes were transplanted using a platinum loop to Petri dishes containing the media PDA, Czapek-Dox Agar (CZ) (Merck) and Malt Extract Agar (MEA) (DIFCO), incubated at $28^{\circ} \mathrm{C} \pm 1$, reactivating their macromorphological characteristics for identification of the various genera, as per the work of Barron (1977).

An optical microscope (Nikon model SZM-1) was used to observe the micromorphological characteristics for species identification, according to the method of Rivalier and Seydel (1932), also using the works of Raper and Fennell (1965), Ellis (1971, 1976), Pitt $(1979,1985)$ and Arx (1981). The specimens were stained with lactophenol of Amann with cotton blue for mounting between the slides and slide covers.

The colonies identified as Aspergillus sp. and Penicillium sp. were transferred to Petri dishes containing MEA 2\% and modified CZ according to Pitt $(1979,1985)$ and Klich and Pitt (1988), and incubated at $28^{\circ} \mathrm{C} \pm 1$. The micromorphological characteristics of the two genera of these species were observed again using the method of Rivalier and Sydel (1932), stained with lactophenol of Amann and cotton blue (20 g of phenol, Reagente Quimibras; $20 \mathrm{ml}$ of lactic acid, Merck; $20 \mathrm{ml}$ of distilled water; $40 \mathrm{ml}$ of glycerin, Merck; $0.05 \mathrm{~g}$ of cotton blue, Sigma).

The colonies identified as Cladosporium sp., Alternaria sp. and Curvularia sp. were transferred to Petri dishes $(9 \mathrm{~cm})$ containing the media PDA and MEA. These identifications were based on the work of Ellis $(1971,1976)$.

The strains of the Mucorales Order were identified according to Arx (1981) since the Genera belonging to this order are not considered entomopathogenic; so it was not necessary to identify the remaining taxonomic categories.

All the isolated fungi were preserved in hemolysis tubes $(15 \times 100 \mathrm{~mm})$ with PDA, under a $1 \mathrm{~cm}$ layer of sterilized mineral oil.

\section{RESULTS}

Forty-two isolates were identified: 10 of A.flavus Link; 6 of A. niger var. niger Van Tieghem; 9 of P. corylophilum Dierckx; 5 of P. fellutanum Biourge; 2 of $C$. cladosporoides (Fresen.) de Vries; 2 of Fusarium Link, and 5 of A. alternata Fries. There were only one isolate each of the colonies identified as $C$. brachyspora Boedjn, M. sterilia and the Mucorales order. Table I shows the frequency of these fungi for the respective breeding grounds where they were collected.

The most prevalent species were A. flavus and $P$. corylophilum. Among the flies taken from the pigpens, $33.4 \%$ of the isolates were identified as A. flavus and $26.7 \%$ as $P$. corylophilum. These two fungal species were also the most frequent among the flies captured at the landfill, with a frequency of $18.5 \%$ for both (Table I).

Climatic data for the periods in which the collection was conducted, obtained from the Pesagro/Rio Experimental Station, are shown in Table II.

\section{DISCUSSION}

In the fungi isolated from $M$. domestica, we observed a prevalence of the genus Aspergillus, followed by the genus Penicillium. Various researchers have isolated fungal species from insects. Burnside (1932) isolated $A$. flavus, A. niger and P. corylophilum from bees. Gillian and Prest (1972) and Gillian et al. (1974) also isolated various fungi from bees, identifying the species A. niger, A. flavus, P. corylophilum, C. cladosporoides and Alternaria sp. We found all these species in the present study, and as in the works cited above, the most prevalent was A. flavus.

Costa and Oliveira (1998) isolated various species of Penicillium from mosquito vectors of tropical diseases, the most prevalent being, in decreasing order, $P$. corylophilum, $P$. janthinellum and $P$. fellutanum. The two species of Penicillium isolated from $M$. domestica in this study were $P$. corylophilum and $P$. fellutanum, with the first being most prevalent, in line with the results reported by Costa and Oliveira (1998).

Norberg et al. (1999) verified the predominance of the genus Penicillium in adult Muscidae dipterons $(M$. domestica among others), captured in hospitals, bars and outdoor markets in the back-bay lowlands surrounding Rio de Janeiro's Guanabara Bay (Baixada Fluminense). These authors also reported the isolation of other species, such as: A. fumigatus, A. niger, Fusarium sp., Alternaria sp. and C. albicans, among the most frequent. Some of these genera and species were isolated from adults of $M$. domestica in the present study. In another work on isolation and identification of fungi in Muscidae dipterons, Kaaya and Okech (1990) reported various species isolated from pupae and adults of Glossina pallidipes, among which A. flavus, A. niger, Penicillium sp. and Fusarium 
TABLE I

Fungal isolates obtained from Musca domestica captured at two natural breeding grounds, the Swine Culture Sector, Zootecnia (Universidade Federal Rural do Rio de Janeiro) and the Boa Esperança sanitary landfill in the municipality of Seropédica, State of Rio de Janeiro

\begin{tabular}{lrrr}
\hline & \multicolumn{2}{c}{ Number isolates for habitats $(\%)$} & Total \\
\cline { 2 - 4 } Species & Swine breeding & City dump & $10(23.8)$ \\
\hline Aspergillus flavus & $5(33.4)$ & $5(18.5)$ & $6(14.4)$ \\
A. niger var. niger & $2(13.3)$ & $4(14.9)$ & $9(21.4)$ \\
Penicillium corylophilum & $4(26.7)$ & $5(18.5)$ & $5(11.9)$ \\
P. fellutanum & $2(13.3)$ & $3(11.1)$ & $2(4.7)$ \\
Cladosporium cladosporoides & - & $2(7.4)$ & $2(4.7)$ \\
Fusarium sp. & - & $2(7.4)$ & $5(11.9)$ \\
Alternria alternata & $2(13.3)$ & $3(11.1)$ & $1(2.4)$ \\
Curvularia brachyspora & - & $1(3.7)$ & $1(2.4)$ \\
Mycelia sterilia & - & $1(3.7)$ & $1(2.4)$ \\
Mucorales & - & $1(3.7)$ & 42 \\
\hline Total & 15 & 27 & 4 \\
\hline
\end{tabular}

\section{TABLE II}

Climate readings for the period in which the specimens of Musca domestica were collected in Seropédica, State of Rio de Janeiro, taken at the Pesagro/Rio de Janeiro Experimental Station

\begin{tabular}{lcccc}
\hline & \multicolumn{2}{c}{ Average temperature $\left({ }^{\circ} \mathrm{C}\right)$} & $\begin{array}{c}\text { Relative } \\
\text { humidity } \\
\text { Month/1999 }\end{array}$ & $\begin{array}{r}\text { Maximum } \\
\text { Insolation } \\
\text { (hours) }\end{array}$ \\
\cline { 2 - 3 } February & 31.1 & 22.6 & 64.3 & 176.6 \\
March & 31.2 & 21.7 & 68.3 & 204.1 \\
April & 28.5 & 19.1 & 68.3 & 179.5 \\
May & 26.7 & 16.0 & 61.0 & 189.2 \\
June & 24.9 & 15.9 & 70.0 & 156.3 \\
July & 25.3 & 16.0 & 64.7 & 175.5 \\
August & 26.3 & 14.1 & 58.3 & 210.7 \\
September & 28.3 & 16.9 & 57.7 & 166.3 \\
\hline
\end{tabular}

sp. stood out, as in our study with $M$. domestica. These authors theorized that the fungi infected the Muscidae during the pupa stage through direct contact with soil. According to Steinkraus (1990), soil contains naturally distributed conidia or the corpses of contaminated arthropods, which can infect Muscidae pupae that come in direct contact with this medium after abandoning the larval substrate for pupation. The author considers that these fungi can spread to newly emerged adult Muscidae through contact with the infected pupae.

Sarquis and Oliveira (1996) isolated and identified fungi from the soil in the State of Rio de Janeiro and found the genera Aspergillus, Penicillium, Fusarium and Cladosporium among the most common, once again showing that these species are present in soil that is also used by Muscidae for pupation.

Of the genera of fungi reported by Steinhaus (1946) as pathogenic for insects, in this study we isolated Aspergillus, Fusarium and Penicillium. This author pointed out the importance of temperature and relative humidity conditions in the occurrence of these fungal species. A moist environment favors germination and hastens the development of spores, and normally the temperature range best suited for development of most entomogenous fungi is between 20 and $30^{\circ} \mathrm{C}$. He also reported that the population density of the hosts and luminosity were also important factors for development of epizootic diseases. We encountered similar conditions in the two locations we collected the fly samples. In the period for collection and isolation of fungal strains, the temperature measured at the Pesagro/RJ Experimental Station were in the same range as found by Steinhaus (1946) to be propitious for fungal growth. The municipality of Seropédica has a generally hot and humid climate.

At the municipal landfill, the density of $M$. domestica was even higher than at the pigpens. The abundant organic material favored the development of this species of fly. As an omnivorous species, $M$. domestica can use different substrates in the larval stage (Hewitt 1914). Although pig dung has been cited by various authors as one of the best substrates for development of this fly (Geetha Bai \& Sankaran 1977, Senna-Nunes et al. 1991), we found a lower density in this breeding ground, probably because the pigpens were cleaned and the dung removed regularly.

The insalubrious conditions at the city dump could have contributed to the greater diversity of the fungal species isolated. C. cladosporoides, Fusarium sp., C. brachyspora, $M$. sterilia and the order Mucorales were only isolated from flies captured at the dump. Bergen and Wagner-Merner (1977) also found that a greater number of fungal species found in determined places could be attributed to bioclimatic factors, favoring or interfering in the dispersion and survival of fungi. These authors also state that a greater number of substrates found in certain places can create favorable conditions for fungal growth. In the present study, the bioclimatic conditions were identical for the two collection locations and hence were not a factor in the variation. However, there were a wider variety of substrates at the city dump, favoring greater fungal diversity. These data confirm the findings of the above 
mentioned authors.

E. muscae, despite being a fungal species often found associated with $M$. domestica, was not isolated in the present study. Salles and Hathaway (1944) pointed out that this species prefers moist, cool environments, unlike those usually present in Rio de Janeiro.

\section{ACKNOWLEDGMENTS}

To technician Ivan Serafim da Silva for his help in collecting the insects.

\section{REFERENCES}

Alves SB 1998. Controle Microbiano de Insetos, Vol. 4, 2a. ed., Fealq, São Paulo, 1163 pp.

Arx JA Von 1981. The Genera of Fungi Sporulating in Pure Culture, 3rd ed., J Cramer, Vaduz, Germany, 215 pp.

Barron GL 1977. The Genera of Hyphomycetes from Soil, Robert E. Krieger Publishing Co., Huntington, New York, $364 \mathrm{pp}$.

Bergen L, Wagner-Merner DT 1977. Comparative survey of fungi and potential pathogenic fungi from selected beaches in the Tampa bay area. Mycologia 69: 299-308.

Burnside CE 1932. Fungus Diseases of the Honeybee, Vol. 149, Bulletin Technical of U.S. Department Agriculture, Washington, $279 \mathrm{pp}$.

Costa GL, Oliveira PC 1998. Penicillium species in mosquitoes from two Brazilian regions. J Basic Microbiol 38: 343-347.

Ellis MB 1971. Dematiaceous Hyphomycetes, 2nd ed., CAB Press, Kew, Surrey, England.

Ellis MB 1976. More Dematiaceous Hyphomycetes, CAB Press, Kew, Surrey, England.

Freitas MG, Costa HMA, Costa JO, Iide P 1981. Entomologia e Acarologia Médica e Veterinária, 5a. ed., Precisa Editora Gráfica Ltda, Belo Horizonte, 253 pp.

Geetha Bai M, Sankaran T 1977. Parasites, predators and other arthropods associated with $M$. domestica and other files breding in bovine manure. Entomophaga 22: 163-167.

Gilliam M, Prest DB 1972. Fungi isolated from the intestinal contents of foraging worker honey bees, Apis mellifera. $J$ Invert Pathol 20: 101-103.

Gilliam M, Prest DB, Morton HL 1974. Fungi isolated from Honey Bess, Apis mellifera, Fed 2,4-D and antibiotics. $J$ Invert Pathol 24: 213-217.

Gough PM, Jorgenson RD 1983. Identification of porcine transmissible gastro-enteritis virus in house flies (Musca domestica Linneaus). Am J Vet Res 44: 2078-2082.

Greenberg B 1970. Flies and Disease. Ecology, Classification and Biotic Associations, Vol. I, Univ. Press Princeton, New Jersey, $856 \mathrm{pp}$.

Greenberg B 1973. Flies and Disease. Biology and Disease Transmission, Vol. II, Univ. Press Princeton, New Jersey, $447 \mathrm{pp}$.

Hall IM 1964. Use of microorganisms in biological control. In P De Bach, Biological Control of Insect Pests and Weed,
Reinhold Publishing Co., New York, p. 610-628.

Hall RA, Papierok B 1982. Fungi as biological control agents of arthropods of agricultura and medical importance. Parasitology 84: 205-240.

Hewitt CG 1914. The House Fly Musca domestica Linn. Its Structure, Habits Development Relation to Disease and Control, The University Press, Cambridge, 195 pp.

Kaaya GP, Okech MA 1990. Microorganisms associated with tsetse in nature: preliminary results on isolation, identification and pathogenicity. Insect Sci Applic 11: 443-448.

Klich M, Pitt JI 1988. A Laboratory Guide to the Common Aspergillus Species an their Teteomorphs, CSIRO Division of Food Processing, North Ryde, 134 pp.

Madeira NG 1998. Persistence of conidia of Entomophthora muscae in relation to age, temperature, and humidity. BioControl 43: 87-95.

Messias LC 1989. Fungos, sua utilização para controle de insetos de importância médica e agrícola. Mem Inst Oswaldo Cruz 84: 57-59.

Norberg AN, Queiroz MMC, Maure EAP, Toledo RF, Gazeta GS, Norberg CMBM, Guimarães RR 1999. Vetoração de fungos por moscas sinantrópicas coletadas em hospitais, restaurantes e feiras da Baixada Fluminense, Rio de Janeiro, Brasil. In XIV Congreso Latinoamericano de Parasitologia, Acapulco, México, p. 84.

Pitt JI 1979. The Genus Penicillium, Academic Press, London, $635 \mathrm{pp}$.

Pitt JI 1985. A Laboratory Guide to Common Penicillium Species, Academic Press, Australia, $182 \mathrm{pp}$.

Raper KB, Fennell DI 1965. The Genus Aspergillus, The Williams \& Wilks Co., Baltimore, 686 pp.

Rivalier E, Sydel S 1932. Nouveau procedé de culture sur lames gélosées appliqué a létude microspique des champignos deteignes. Ann Parasitol 10: 444-452.

Salles JF, Hathaway CR 1944. Nota sobre a infestação de Musca domestica Linneu, 1758 por um ficomiceto do gênero Empusa. Mem Inst Oswaldo Cruz 41: 95-99.

Sarquis MIM, Oliveira PC 1996. Diversity of microfungi in the sandy soil of Ipanema Beach, Rio de Janeiro, Brazil. J Basic Microbiol 36: 51-58.

Senna-Nunes MS, Milward-de-Azevedo EMV, Carvalho EHPS, Mello RP 1991. Estudo comparado do desenvolvimento pós-embrionário de Musca domestica L. 1758, criada em fezes de animais domésticos, sob condições de laboratório. Revta Bras Ent 35: 203-221.

Seymour R, Cowgill MM, Klecka GM, Gersich FM, Mayes MA 1984. Occurrence of Aphanomyces daphiniae infection in laboratory cultures of Daphnia magna. J Invert Pathol 43: 109-113.

Steinhaus EA 1946. Insect Microbiology, Comstock Publishing Co., New York, 763 pp.

Steinkraus DC, Geden CJ, Rutz DA, Kramer JP 1990. First report of the natural occurrence of Beauveria bassiana (Moniliaceae-Moniliales) in Musca domestica (Diptera, Muscidae). J Med Entomol 27: 309-312. 